\title{
PENINGKATAN PROFESIONALITAS GURU DALAM PEMANFAATAN LINGKUNGAN SEKOLAH SEBAGAI SUMBER BELAJAR MELALUI DISKUSI KELOMPOK KERJA GURU (KKG) TK ISLAM TERPADU AL AZKA
}

\author{
HASNAH \\ TK Islam Terpadu Al Azka \\ Email: hasnah0568@gmail.com
}

\begin{abstract}
ABSTRAK
Penelitian tindakan sekolah (PTS) ini dilaksanakan dengan tujuan meningkatkan profesionalitas guru dalam pemanfaatan lingkungan sekolah sebagai sumber belajar. Penelitian ini dirancang dalam bentuk Penelitian Tindakan Sekolah yang direncanakan dalam dua siklus, di mana setiap siklusnya dilaksanakan dalam dua kali pertemuan. Adapun subyek penelitian ini adalah guru-guru di TK Islam Terpadu Al Azka Kota Jambi yang terdiri darienam orang guru.

Pelaksanaan penelitian ini diawali dengan pengumpulan data dan menggunakan format observasi, instrumen penilaian skenario pembelajaran dan instrumen penilaian pelaksanaan pembelajaran. Selanjutnya data yang sudah terkumpul dianalisis dengan menggunakan analisis deskriptif yang hasilnya adalah pada siklus I nilai rata-rata yang diperoleh adalah 79,38, sedangkan pada siklus II nilai rata-rata yang diperoleh adalah 84,88 . Sehingga dapat disimpulkan bahwa pembinaan dan bimbingan melalui pendekatan diskusi kelompok kerja guru dapat meningkatkan profesionalitas guru dalam pemanfaatan lingkungan sekolah sebagai sumber belajar bagi guru-guru di TK Islam Terpadu Al Azka.
\end{abstract}

\section{Kata kunci: Profesionalitas Guru, Sumber Belajar, KKG}

\section{A. PENDAHULUAN}

\section{Latar Belakang Masalah}

Salah satu agenda pemerintah untuk meningkatkan kualitas pendidikan nasional adalah penyempurnaan kurikulum.Pelaksanaan sistem kurikulum nasional yang sentralistik telah menghasilkan prilaku kognitif siswa yang kurang fleksibel, kurang terbuka terhadap pendapat yang divergen. Siswa merasa lebih aman dan cendrung terikat pada apa yang telah ada, pikiran mereka kurang berkembang dan cenderung kurang suka pada sesuatu yang baru. Praktek-praktek pendidikan yang dikembangkan kelihatannya lebih ditekankan pada pemikiran 
reproduktif, menekankan pada hafalan dan mencari satu jawaban benar terhadap soal-soal yang diberikan.Akhirnya kompetensi belajar kurang berkembang secara optimal.

Untuk itu sesuai Kurikulum K 13 yang berlaku sekarang ini, memerlukan strategi baru terutama dalam kegiatan pembelajaran. Pendekatan pembelajaran yang sebelumnya lebih banyak didominasi oleh peran guru (teacher centered) diperbaharui dengan sistem pembelajaran yang berpusat pada siswa (student centered). Dalam implementasi K-13, guru harus mampu memilih dan menerapkan model, motode atau strategi pembelajaran yang sesuai dengan karakteristik materi sehingga mampu mengembangkan daya nalar siswa secara optimal.Dengan demikian dalam pembelajaran guru tidak hanya terpaku dengan pembelajaran di dalam kelas, melainkan guru harus mampu melaksanakan pembelajaran dengan motode yang variatif.

Salah satu strategi pembelajaran yang sesuai dengan pendekatan Pakem yang memungkinkan bisa mengembangkan kreativiats, motivasi dan partisipasi siswa dalam pembelajaran adalah dengan pemanfaatan lingkungan sekolah sebagai sumber belajar.Hal ini juga sesuai dengan salah satu pilar dari pendekatan contekstual yaitu masyarakat belajar (learning commonity). Untuk mencapai tujuan tersebut, salah satu cara belajar yang disarankan dalam Kurikulum K 13, sebagai upaya mendekatkan aktivitas belajar siswa pada berbagai fakta kehidupan sehari-hari di sekitar lingkungan siswa.

Pemanfaatan lingkungan sekolah sebagai sumber belajar menjadi alternatif setrategi pembelajaran untuk memberikan kedekatan teoritis dan praktis bagi pengembangan hasil belajar siswa secara optimal.Menurut Pantiwati lingkungan sekolah adalah kesatuan ruang dalam lembaga pendidikan formal yang memberikan pengaruh pembentukan sikap dan pengembangan potensi siswa.

Ekowati mengatakan, pemanfaatan lingkungan sekolah sebagai sumber belajar merupakan bentuk pembelajaran yang berpihak pada pembelajaran melalui penggalian dan penemuan (experiencing) serta keterkaitan (relating) antara materi pelajaran dengan konteks pengalaman kehidupan nyata melalui kegiatan proyek. Pada pembelajaran dengan setrategi ini guru bertindak sebagai pelatih 
metakognitif yaitu membantu pelajar dalam menemukan materi belajar, mengintegrasikan pengetahuan dan ketrampilan dalam pembuatan laporan dan dalam penampilan hasil dalam bentuk presentasi.

Dari hasil pantauan peneliti selaku kepala sekolah, selama ini para guru masih sangat jarang memanfaatkan lingkungan sekolah sebagai sumber belajar.Lingkungan sekolah tidak lebih hanya digunakan sebagai tempat bermainmain siswa pada saat istirahat. Kalau tidak jam istirahat, guru lebih sering memilih mengkarantina siswa di dalam kelas, walaupun misalnya siswa sudah merasa sangat jenuh berada di dalam kelas.

Pembelajaran adalah proses interaksi peserta didik dengan guru dan sumber belajar pada suatu lingkungan belajar (UU SISDIKNAS No. 20 Tahun 2003 Pasal 1). Ada dua proses yang saling berkaitan dalam pembelajaran yang pada hakekatnya tidak dapat dipisahkan satu sama lain, yaitu proses belajar dan proses mengajar. Proses belajar dapat terjadi kapan saja dan dimana saja terlepas dari ada yang mengajar atau tidak. Proses belajar terjadi karena adanya interaksi individu dengan lingkungan.

Belajar merupakan proses kompleks yang terjadi pada semua orang dan berlangsung seumur hidup. orang tidak akan berhentinya belajar selama dia membutuhkan pengetahuan yang diperlukannya. Dalam pembelajaran guru bukanlah satu-satunya sumber belajar, walaupun tugas, peranan, dan fungsingnya dalam proses belajar mengajar sangatlah penting.

Observasi awal yang penulis lakukan, guru-guru memanfaatkan lingkungan sekolah sebagai sumber belajar hanya dua sampai tiga kali dalam satu semester. Guru lebih sering menyajikan pelajaran di dalam kelas walaupun materi yang disajikan berkaitan dengan lingkungan sekolah. Sebagian besar guru menyatakan belum memanfaatkan lingkungan sebagai sumber belajar secara maksimal, guru hanya mengajak siswa belajar di luar kelas, karena ingin melakukan pengawasan dimana siswa ingin mencari suasana yang berbeda dengan belajar di dalam kelas, disamping hal tersebut siswa susah diawasi jika dilaksanakan pembelajaran di luar kelas. 
Selain itu ada guru yang menyampaikan bahwa mereka tidak bisa dan tidak tahu dalam pemanfaatan lingkungan sekolah sebagai sumber belajar, dan perlu adanya petunjuk yang jelas.Untuk mengatasi hal itu perlu adanya diskusi kelompok diantara para guru kelas dalam bentuk KKG sebagai suatu wadah yang dapat berfungsi untuk mendiskusikan masalah-masalah pembelajaran diantaranya adalah tentang pemanfaatan lingkungan sekolah sebagai sumber belajar.

Manfaat nyata yang dapat diperoleh dengan pemanfaatan lingkungan ini adalah: (1) menyediakan berbagai hal yang dapat dipelajari anak, (2) memungkinkan terjadinya proses belajar yang lebih bermakna (meaningful learning), (3) memungkinkan terjadinya proses pembentukan kepribadian anak, (4) kegiatan belajar akan lebih menarik bagi anak, dan (5) menumbuhkan aktivitas belajar anak (learning aktivities).

Dalam kegiatan diskusi tersebut para guru bisa membagi pengalaman yang pernah dialaminya terutama dalam pemanfaatan lingkungan sekolah sebagai sumber belajar untuk mencapai hasil belajar yang optimal.Penelitian Nur Mohamad dan Ekowati menunjukkan diskusi kolompok memiliki dampak yang amat positif bagi guru yang tingkat pengalamannya rendah maupun yang tingkat pengalamannya tinggi.

Bagi guru yang tingkat pengalamannya tinggi akan menjadi lebih matang dan bagi guru yang tingkat pengalamannya rendah akan menambah pengetahuan. Keunggulan diskusi kelompok melalui KKG adalah keterlibatan guru bersifat holistic dan konprehensip dalam semua kegiatan.Dari segi lainnya guru dapat menukar pendapat, memberi saran, tanggapan dan berbagai reaksi sosial dengan teman seprofesi sebagai peluang bagi mereka untuk meningkatkan profesionalitasdan pengalaman.

Menurut Alwi membentuk Kelompok Kerja Guru (KKG), karena wadah ini memiliki banyak manfaat diantaranya sebagai tempat menampung dan memecahkan masalah yang dihadapi guru dalam kegiatan belajar mengajar, diskusi, contoh mengajar, demonstrasi penggunaan dan pembuatan alat peraga. Dengan adanya KKG, diharapkan dapat memberikan keleluasaan terhadap pengelolaan proses pembelajaran. 
Supriadi mengemukakan bahwa keberhasilan pengelolaan pendidikan bergantung pada kualitas para guru.Kedudukan dan peran guru sangat besar pengaruhnya dan merupakan titik yang strategis dalam kegiatan pendidikan. Guru bukan hanya cerdas dan mempunyai gelar, akan tetapi juga mempunyai karakter beriman, bertaqwa, berahlak mulia, berbudi pekerti luhur, dan mengamalkan ilmunya secara bertanggung jawab. Melalui KKG sekolah, guru melakukan kegiatan pertemuan untuk mendiskusikan berbagai persoalan yang berkaitan dengan proses belajar mengajar. Namun, untuk membina dan mengembangkan profesionalisme guru, tidak cukup mengandalkan preservice training.

Oleh karena kurang optimalnya guru-guru memanfaatkan lingkungan sebagai sumber belajar maka Peneliti ingin meningkatkan profesioinalitasnya dengan mengoptimalkan peran KKG dalam membina guru bagaimana memanfaatkan lingkungan sebagai sumber belajar. Berkaitan dengan hal tersebut diatas maka dalam Penelitian Tindakan Sekolah ini Peneliti mengangkat judul: "Peningkatan Profesionalitas Guru Dalam Pemanfaatan Lingkungan Sekolah Sebagai Sumber Belajar Melalui diskusi Kelompok Kerja Guru (KKG) di TK Islam Terpadu Al Azka.

\section{Rumusan Masalah}

Adapun rumusan masalah dalam penelitian ini adalah: Apakah dengan diskusi kerja kelompok kerja guru (KKG) dapat meningkatkan Profesionalitas Guru Dalam Pemanfaatan Lingkungan Sekolah Sebagai Sumber Belajar?

\section{Tujuan Penelitian}

Untuk mengetahui dan menganalisis apakah dengan diskusi kerja kelompok kerja guru (KKG) dapat meningkatkan Profesionalitas Guru Dalam Pemanfaatan Lingkungan Sekolah Sebagai Sumber Belajar.

\section{Manfaat Penelitian}

Penelitian ini diharapkan dapat bermanfaat bagi siswa, guru dan kepala sekolah dalam meningkatkan aktivitas pembelajaran, peningkatan profesionalitas 'guru serta dapat meningkatkan kinerja sekolah. 


\section{B. KAJIAN TEORI}

\section{Pengertian Profesionalisme Guru}

Kompetensi profesional guru yaitu kemampuan penguasaan akademik (mata pelajaran yang diajarkan) dan terpadu dengan kemampuan mengajarnya sekaligus sehingga guru itu memiliki wibawa akademis". ${ }^{1}$ Kompetensi profesional yang dimaksud adalah kemampuan guru untuk menguasai masalah akademik yang sangat berkaitan dengan pelaksanaan proses belajar-mengajar, sehingga kompetensi ini mutlak dimiliki guru dalam menjalankan tugasnya sebagai pendidik dan pengajar.

Para pakar dan ahli pendidikan mengemukakan bahwa kompetensi guru merupakan salah satu syarat yang pokok dalam pelaksanaan tugas guru dalam jenjang apapun. Pengertian kompetensi seperti yang dinyatakan dalam UU No 14 Tahun 2005 tentang Undang-Undang Guru dan Dosen menyebutkan bahwa Kompetensi adalah seperangkat pengetahuan, ketrampilan, dan perilaku yang harus dimiliki, dihayati, dan dikuasai oleh guru dalam melaksanakan tugas keprofesionalan.

Dengan demikian kompetensi pada hakekatnya terdiri atas aspek kognitif, psikomotorik, dan afektif. Lebih khusus berkenaan dengan kompetensi guru, pada RPP Guru, pasal 4 ayat (2) dinyatakan bahwa kompetensi guru terdiri dari atas empat komponen, yairu kompetensi profesional, kompetensi pedagogik, kompetensi sosial dan kompetensi personal. Selanjutanya pada RPP Guru pasal 4 ada lima ayat yaitu ayat (3), ayat (4), ayat (5), ayat (6), dan ayat (7) yang terkait dengan kompetensi guru.

Peningkatan profesionalisme dalam proses belajar mengajar akan sangat menentukan keberhasilan suatu tujuan pendidikan. Keberhasilan profesionalisme guru juga tidak bisa terlepas dari peran kepala sekolah salah satunya adalah adanya pengawasan kepala sekolah, yaitu dengan adanya pengawasan langsung dari kepala sekolah seperti kehadiran, kedisiplinan, dedikasi kerja, menyediakan sarana prasarana bahkan memperhatikan kesejahteraan para guru tersebut.

\footnotetext{
${ }^{1}$ Piet A.Sahertian, Supervisi Pendidikan Dalam Rangka Program Inservice Eduacation (Surabaya:.Usaha Nasional, 1990), hal. 32
} 
Dengan demikian upaya peningkatan profesionalisme guru dalam proses belajar mengajar di sekolah akan terwujud sesuai dengan harapan dan tujuan pendidikan.

\section{Sumber Belajar}

Sumber belajar memiliki pengertian yang sangat luas.Sumber belajar menurut Ahmad Rohani \& Abu Ahmadi, ${ }^{2}$ adalah guru dan bahan-bahan pelajaran berupa buku bacaan atau semacamnya. Pengertian selanjutnya dari sumber belajar adalah segala daya yang dapat dipergunakan untuk kepentingan proses pembelajaran baik langsung maupun tidak langsung, di luar diri peserta didik yang melengkapi diri mereka pada saat pembelajaran berlangsung.

Sumber belajar adalah segala sesuatu yang dapat mendukung proses belajar sehingga memberikan perubahan yang positif. Hal tersebut sesuai dengan pernyataan Arif S Sadiman (dalam Ahmad Rohani \& Abu Ahmadi ${ }^{3}$, yang berpendapat bahwa sumber belajar adalah segala macam sumber yang ada di luar yang memungkinkan terjadinya proses belajar. Peranan sumber-sumber belajar (seperti: guru, dosen, buku, film, majalah, laboratorium, peristiwa, dan sebagainya) memungkinkan individu berubah dari tidak tahu menjadi tahu, dari tidak mengerti menjadi mengerti, dar tidak terampil menjadi terampil, dan menjadikan individu dapat membedakan mana yang baik dan mana yang tidak baik.

Jadi segala apa yang bisa mendatangkan manfaat atau mendukung dan menunjang individu untuk berubah ke arah yang lebih positif, dinamis, atau menuju perkembangan dapat disebut sumber belajar. Sumber belajar adalah segala sesuatu yang dapat memberikan informasi dalam pembelajaran.Abdul Majid mengungkapkan bahwa sumber belajar ditetapkan sebagai informasi yang disajikan dan disimpan dalam berbagai bentuk media, yang dapat membantu siswa dalam belajar, sebagai perwujudan dari kurikulum. ${ }^{4}$

\footnotetext{
${ }^{2}$ Ahmad Rohani HM dan Abu Ahmadi, Pengelolaan Pengajaran.(Jakarta: Rineka Cipta, 1995), hal.152

${ }^{3}$ Ibid, hal.152-153

${ }^{4}$ Abdul Majid,Perencanaan Pembelajaran, Mengembangkan Standar Kompetensi Guru, (Jakarta: PT. Rosda Karya, 2008), hal. 170
} 
Berdasarkan beberapa pendapat ahli di atas dapat disimpulkan bahwa sumber belajar adalah segala sesuatu yang dapat digunakan oleh siswa untuk mempelajari suatu hal.Pengertian dari sumber belajar sangat luas. Sumber belajar tidak terbatas hanya buku saja tetapi dapat berupa, orang, alat, bahan, dan lingkungan yang dapat mendukung proses pembelajaran.

AECT (Association of Education Communication Technology) mengklasifikasikan sumber belajar dalam enam macam yaitu message, people, materials, device, technique, dan setting (Akhmad Rohani \& Abu Ahmadi, 1995: 155). Enam klasifikasi sumber belajar tersebut dapat dijelaskan sebagai berikut:

a. Message (pesan), yaitu informasi/ajaran yang diteruskan oleh komponen lain dalam bentuk gagasan, fakta, arti dan data.

b. People (orang), yakni manusia yang bertindak sebagai penyimpan, pengolah, dan penyaji pesan. Termasuk kelompok ini misalnya dosen, guru, tutor, dll.

c. Materials (bahan), yaitu perangkat lunak yang mengandung pesan untuk disajikan melalui penggunaan alat/perangkat keras, ataupun oleh dirinya sendiri. Berbagai program media termasuk kategori materials, seperti transportasi, slide, film, audio, video, modul, majalah, buku dan sebagainya.

d. Device (alat), yakni sesuatu (perangkat keras) yang digunakan yang digunakan untuk menyampaikan pesan yang tersimpan dalam bahan. Misalnya overhead proyektor, slide, video tape/recorder, dll

e. Technique (teknik), yaitu prosedur atau acuan yang dipersiapkan untuk penggunaan bahan, peralatan, orang, lingkungan untuk menyampaikan pesan. Misalnya pengajaran terprogram/modul, simulasi, demonstrasi, tanya jawab, dll.

f. Setting (lingkungan), yaitu situasi atau suasana sekitar dimana pesan disampaikan. Baik lingkungan fisik ataupun non fisik.

Berdasarkan klasifikasi di atas, sumber belajar dapat digolongkan menjadi: pesan, orang, alat, bahan, teknik, dan lingkungan. Penelitian ini mengembangkan sumber belajar bentuk majalah.Berdasarkan klasifikasi di atas, dapat dilihat majalah merupakan salah satu bentuk sumber belajar yang termasuk ke dalam klasifikasi sumber belajar bahan atau materials.Majalah mengandung pesan yang 
dapat menjadi sumber belajar bagi siswa.Majalah merupakan sumber informasi aktual yang dapat digunakan secara mandiri oleh siswa.

\section{Kelompok Kerja Guru}

Kelompok Kerja Guru (KKG) merupakan wadah atau forum kegiatan profesional bagi para guru Sekolah Dasar/ Madrasah Ibtidaiyah di tingkat gugus atau kecamatan yang terdiri dari beberapa sekolah.Kelompok Kerja Guru (KKG) adalah wadah kegiatan profesional bagi guru SD/MI/SDLB di tingkat kecamatan yang terdiri dari sejumlah guru dari sejumlah sekolah.2

Menurut Mulyasa, Kelompok Kerja Guru (KKG) adalah forum komunikasi kerja guru, dari guru, oleh guru, dan untuk guru. Forum ini memiliki tugas dan fungsi untuk membahas masalah-masalah yang dihadapi dalam pembelajaran dengan menciptakan iklim yang kondusif agar para guru dapat berekreasi didalamnya. ${ }^{5}$ Kelompok Kerja Guru adalah wadah kerja sama guruguru dalam suatu kelompok, dalam upaya meningkatkan kemampuan profesional mereka.

Selain itu, Kelompok kerja guru (KKG) merupakan pendekatan yang paling efektif dan terarah dalam mengembangkan diri yang sekaligus berdampak bagi kinerja mengajar guru.Kemampuan kinerja mengajar guru sangat diperlukan, karena guru adalah orang yang terdepan dan merupakan salah satu factor penentu keberhasilan setiap upaya pendidikan.Itulah sebabnya setiap adanya inovasi pendidikan khususnya dalam kurikulum dan peningkatan sumber daya manusia yang dihasilkan dari upaya pendidikan selalu bermuara pada faktor guru.

KKG menjadi salah satu bagian dari sistem pembinaan professional yang dianjurkan sekaligus dibina oleh Kementrian Pendidikan dan Kebudayaan.Kelompok kerja guru merupakan wadah pertemuan professional guru sekolah dasar yang bersifat aktif, kompak dan akrab membahas berbagai masalah professional kependidikan dengan prinsip dari guru, oleh guru dan untuk guru dalam rangka pelaksanaan tugas dan fungsinya disekolah.Pembentukan kelompok

\footnotetext{
${ }^{5}$ E. Mulyasa, Uji Kompetensi dan Penilaian Kinerja Guru, (Bandung: PT Remaja Rosdakarya, 2013), hal. 114
} 
kerja guru berangkat dari kesadaran bahwa guru sebagai profesi dalam meningkatkan kualitas sumber daya manusia perlu terus menerus berusaha meningkatkan kemampuannya dalam melaksanakan pendidikan dan memberi layanan terhadap peserta didik didalam sekolah maupun diluar sekolah. ${ }^{6}$

KKG bertujuan untuk memecahkan berbagai masalah yang berkaitan dengan tugas pokok dan fungsi guru disekolah, juga merupakan wadah kebersamaan guru dalam menentukan perencanaan, pelaksanaan, dan penilaian pembelajaran. Pemberdayaan forum ini lebih berharga lagi setelah kebijakan sertifikasi diberlakukan karena untuk memperoleh sertifikat pendidik, guru harus melakukan berbagai kegiatan yang relevan dengan tugas profesinya.Kegiatan yang dituntunt dalam sertifikasi tersebut sebagian besar dapat dilakukan diforum KKG. Selain itu diforum KKG juga guru dapat bertemu dan sharing dengan guruguru lain yang senasib dan seperjuangan.

\section{METODE PENELITIAN}

\section{Jenis Penelitian}

Penelitian ini adalah Penelitian Tindakan Sekolah (PTS) sehingga dalam pelaksanaannya menekankan pada peningkatan profesionalitas guru dalam memanfaatkan lingkungan sebagai sumber belajar. Subyek Penelitian ini adalah guru TK Islam Terpadu Al Azka yang berjumlah 8 orang. Dari 8 orang guru tersebut dilihat perkembanganya setelah dilakukan tindakan yang dimulai dari siklus I, II .

\section{Setting Penelitian}

Penelitian Tindakan Sekolah ini berlokasi di TK Islam Terpadu Al Azka, yang ditujukan pada guru-guru.Adapun alasan utamanya adalah dari hasil pengamatan dan informasi dari guru, bahwa hampir semua guru belum secara optimal memanfaatkan lingkungan sekolah sebagai sumber belajar.

Jenis tindakan dalam penelitian ini adalah berupa tindakan nyata yaitu membimbing guru memahami pemanfaatan lingkungan sekolah, menyusun

${ }^{6}$ Ibid, hal. 140 
skenario pembelajaran dan pelaksanaan pembelajaran dengan pemanfaatan lingkungan sekolah sebagai sumber belajar melalui diskusi Kelompok Kerja Guru (KKG).

\section{Prosedur Penelitian}

Prosedur penelitian yang dilakukan adalah menggunakan model penelitian tindakan sekolah yang dikembangkan oleh Kemmis \& Taggart, dimana pada prinsipnya ada empat tahap kegiatan yaitu, perencanaan tindakan (planning), pelaksanaan tindakan (action), observasi dan evaluasi proses tindakan (observation and evaluation) dan melakukan refleksi (reflecting). Alur penelitian secara keseluruhan dapat digambarkan sebagai berikut.

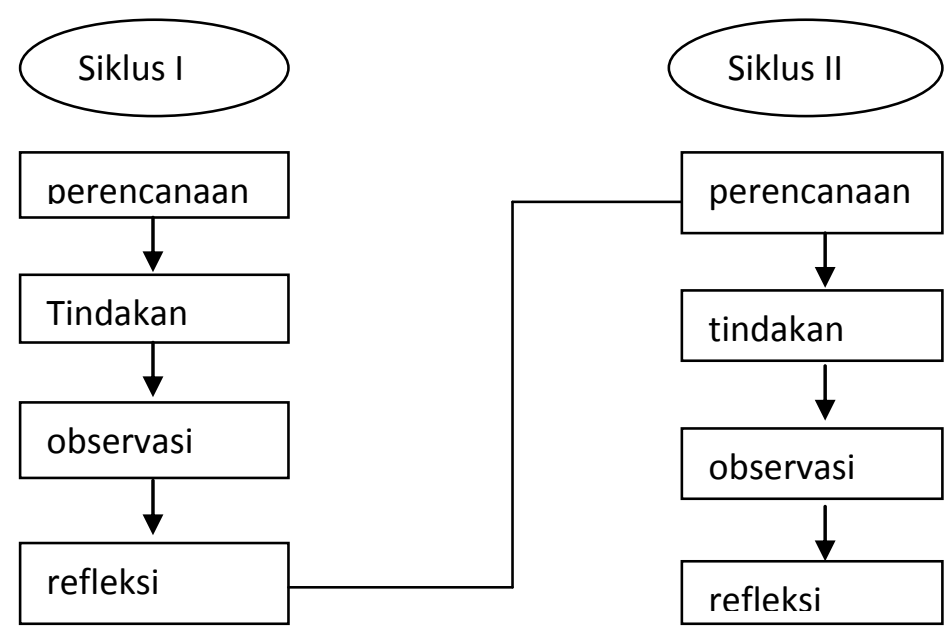

Gambar 1: Alur Penelitian

Secara rinci prosedur tindakan yang dilakukan adalah sebagai berikut.

(1) Membagi guru dalam dua kelompok kecil,

(2) Peneliti memberi penjelasan tentang pemanfaatan lingkungan sekolah sebagai sumber belajar,

(3) Guru menyusun skenario pembelajaran dengan memanfaakan lingkungan sekolah sebagai sumber belajar dalam diskusi kelompok, 
(4) Peneliti membimbing kelompok guru dalam menyusun skenario pembelajaran,

(5) Wakil kelompok guru mempresentasikan skenario pembelajaran,

(6) Peneliti memberi masukan terhadap skenario pembelajaran yang telah dibuat kelompok guru,

(7) Guru melaksanakan skenario pembelajaran dalam proses pembelajaran yang sebenarnya,

(8) Peneliti mengevaluasi profesionalitas guru dalam mengimplementasikan skenario pembelajaran,

(9) Dalam kelompok diskusi guru berbagi pengalaman terkait dengan pelaksanaan pembelajaran yang memanfaakan lingkungan sekolah sebagai sumber belajar,

Target yang diharapkan:

a. Guru mampu membuat skenario pembelajaran dengan memanfaakan lingkungan sekolah sebagai sumber belajar,

b. Guru mampu melaksanakan pembelajaran dengan memanfaakan lingkungan sekolah sebagai sumber belajar,

c. Guru mampu berdiskusi secara aktif dan kreatif,dan mampu pemanfaatan diskusi kelompok kerja guru secara efektif dan efesien dalam memecahkan masalah yang terkait dengan kegiatan pembelajaran.

Pada penelitian ini diharapkan terdapat peningkatan mutu KBM di TK Islam Terpadu Al Azka Kota Jambi. Dimana nantinya akan berdampak pada peningkatan profesionalitas guru dalam memanfaatkan lingkungan sebagai sumber belajar. Hasil akhir yang diperoleh adalah meningkatnya kualitas siswa TK Islam Terpadu Al Azka Kota Jambi.

\section{Metode Pengumpulan Data}

Metode pengumpulan data pada penelitian ini adalah menggunakan angket, lembar observasi dan wawancara.Setelah data diperoleh, dilanjutkan dengan analisis data menggunakan analisis deskriptif. 


\section{HASIL PENELITIAN DAN PEMBAHASAN}

Peneliti melakukan pengamatan pada tahap awal terhadap penggunaan lingkungan sekolah.Hasil yang diperoleh dari prasiklus bahwa sebanyak 6 orang guru yang diamati dalam pemanfaatan lingkungan sekolah sebagai sumber belajar hanya $25 \%$ (2 orang) yang memanfaatkan lingkungan sekolah sebagai sumber belajar, sisanya sebanyak $75 \%$ yang belum memanfaatkan lingkungan sekolah sebagai sumber belajar. Hal ini memerlukan bimbingan dan tuntunan melalui diskusi Kelompok Kerja Guru (KKG), untuk memberikan pemahaman bagi guru yang belum memanfaatkan lingkungan sekolah sebagai sumber belajar.

Data penelitian tindakan sekolah yang diperoleh dari hasil observasi sikap guru dalam kegiatan diskusi kelompok kerja guru tentang pemanfaatan lingkungan sekolah sebagai sumber belajar pada siklus I, hasilnya termasuk katagori "cukup" dengan rata-rata nilai 79,38. Hal ini menunjukkan bahwa guru dalam berdiskusi belum menampakkan kerjasama,aktivitas dan perhatian yang baik terhadap permasalahan pemanfaatan lingkungan sekolah sebagai sumber belajar,sehingga diperlukan bimbingan yang lebih intensif. Namun tingkat pemahaman guru terhadap pemanfaatan lingkungan sekolah sebagai sumber belajar telah terjadi peningkatan dari prasiklus.

Penilaian skenario pembelajaran yang berbentuk rencana pelaksanaan pembelajaran (RPP) hasilnya termasuk katagori "cukup" dengan rata-rata nilai 78.75.Hal ini menunjukkan bahwa profesionalitas guru dalam menyusun skenario pembelajaran dengan pemanfaatan lingkungan sekolah sebagai sumber belajar perlu peningkatan.

Penilaian implementasi pemanfaatan lingkungan sekolah sebagai sumber belajar dalam kegiatan pembelajaran di kelas,hasilnya termasuk katagori "cukup" dengan rata-rata nilai 78.33. Hal ini menunjukkan bahwa guru dalam mengimplementasikan pemanfaatan lingkungan sekolah sebagai sumber belajar melalui kegiatan pembelajaran di kelas belum optimal,sehingga perlu peningkatan. 
Dengan adanya hasil observasi dan penilaian pada kegiatan siklusI maka peneliti melakukan refleksi.Dari refleksi terhadap seluruh kegiatan pada siklus I, maka ditemukan beberapa hambatan yang mengakibatkan belum optimalnya profesionalitas guru pemanfaatan lingkungan sekolah sebagai sumber belajar.

Adapun hambatan-hambatan tersebut,antara lain guru belum sepenuhnya memahami manfaat lingkungan sekolah sebagai sumber belajar, dan guru dalam memilih sumber belajar dan memilih strategi pembelajaran dengan pemanfaatan lingkungan sekolah belum sesuai dengan yang diharapkan. Hal ini terlihat dalam skenario pembelajaran guru pada:

- Aspek 1. jenis sumber belajar dari lingkungan sekolah tidak tercantum, padahal materi pelajaran ada kaitannya dengan lingkungan sekolah;.

- Aspek 2. Kesesuaian antara materi pelajaran dengan media dan setrategi pembelajaran masih kurang;

- Aspek 4. Kesesuaian antara tujuan pembelajaran dengan sumber bahan,lebih banyak hanya mencantumkan buku paket sebagai satu-satunya sumber belajar.

Dari hasil refleksi pelaksanaan pembelajaran di kelas, hambatan-hambatan yang ditemukan adalah sebagai berikut:

- Aspek 1. dalam kegiatan awal,guru tidak memberi informasi tujuan pembelajaran dan waktunya belum sesuai dengan perencanaan;

- Aspek 2. kegiatan inti, langkah - langkah pembelajaran masih didominasi guru dengan metode ceramah sehingga kurang sesuai dengan pembelajaran aktif, kreatif, efektip dan menyenangkan (Pakem);

- Aspek 3. Profesionalitas guru mengkaitkan materi pelajaran dengan lingkungan sekolah belum optimal;

- aspek 6. Penutup pelajaran, guru kurang memberi penekanan tentang lingkungan sekolah. Hambatan-hambatan tersebut akan disempurnakan pada kegiatan siklus II.

Data yang diperoleh dari observasi sikap guru pada siklus II, setelah dianalisis ada peningkatan kearah perbaikan yaitu berada pada katagori "baik", dengan rata-rata nilai 84.88. Sedangkan untuk penilaian skenario pembelajaran dan penilaian pelaksanaan pembelajaran,masing-masing juga ada peningkatan 
yang ke arah yang lebih baik yaitu: untuk skenario pembelajaran berada pada katagori "baik" dengan nilai rata-rata 82.50, dan untuk penilaian pelaksanaan pembelajaran di kelas berada pada katagori "baik" dengan nilai rata-rata 82.08.

Dengan melihat hasil pada siklus II, maka refleksi terhadap hasil yang diperoleh peneliti pada siklus II ini adalah adanya peningkatan profesionalitas guru pemanfaatan lingkungan sekolah sebagai sumber belajar.Hal ini dibuktikan dengan nilai rata-rata yang diperoleh dalam memprogramkan pembelajaran serta dalam implementasinya di kelas yang sudah menunjukkan adanya peningkatan profesionalitas guru untuk pemanfaatan lingkungan sekolah sebagai sumber belajar yang lebih baik.Sedangkan dari jumlah guru, 75\% sudah mencapai kriteria yang ditetapkan.Keseluruhan hasil pada penelitian ini disajikan dalam grafik sebagai berikut.

Dari hasil paparan pada grafik diatas nampak suatu keberhasilan yang dicapai guru setelah dilakukan diskusi Kelompok Kerja Guru (KKG).Pelaksanaan diskusi Kelompok Kerja Guru (KKG) terbukti mampu memberikan wawasan kepada guru produktif dan adaptif dalam rangka meningkatkan profesionalitasnya untuk pemanfaatan lingkungan sekolah sebagai sumber belajar.Setelah dilakukan evaluasi maka hasil Penelitian Tindakan Sekolah yang dilaksanakan di TK Islam Terpadu Al Azka berhasil dengan baik.

\section{E. KESIMPULAN DAN SARAN}

\section{Kesimpulan}

Berdasarkan penelitian yang telah dilakukan, dapat disimpulkan bahwa penerapan diskusi Kelompok Kerja Guru (KKG) di TK Islam Terpadu Al Azka dapat meningkatkan profesionalitas guru dalam pemanfaatan lingkungan sekolah sebagai sumber belajar.

\section{Saran}

Berdasarkan atas simpulan tersebut di atas, ada beberapa hal yang disarankan yaitu :

(1) Kepada guru-guru khususnya guru diTK Islam Terpadu Al Azka, di dalam menyusun skenario pembelajaran agar pemanfaatan semaksimal mungkin 
lingkungan sekolah dan lingkungan siswa yang sesuai dengana materi pembelajaran sebagai sumber belajar,dan mengintensifkan diskusi KKG dalam memecahkan masalah yang dihadapi;

(2) Menularkan ilmunya kepada teman-teman guru lainnya untuk menerapkan pemanfataan lingkungan sekolah dan lingkungan sebagai sarana pembelajaran di sekolah.

(3) Guru diharapkan terus berinovasi dan lebih kreatif dalam meningkatkan mutu pembelajaran dan memanfaatkan media sebagai sarana pembelajaran agar siswa bisa cepat memahami materi yang diajarkan, serta ciptakan suasana pembelajaran yang dinamis untuk mengurangi tingkat kebosanan siswa.

\section{DAFTAR PUSTAKA}

S. Wojowasito, WJS. Poerwadarminto, Kamus Bahasa Inggris IndonesiaIndonesia Inggris, Bandung: Hasta, 1982.

Salim, Yeny salim, Kamus Indonesia Kontemporer, Jakarta: Pres, 1991.

Roestiyah.N. K, Masalah- Masalah Ilmu Keguruan, Jakarta: Bina Aksara, 1986.

M. Surya, dkk, Kapita Selekta Kependidikan, Jakarta: Universetas Terbuka, 2003.

Syafrudin Nurdin, Guru Profesional dan Implementasi Kurikulum, Ciputat: Pers, 2002.

Sadirman A. M, Interaksi dan Motifasi Belajar, Jakarta: Rajawali Pres,1991.

M. Arifin, Kapita Selekta Pendidikan Islam dan Umum, Jakarta: 1993.

Undang-Undang Republik Indonesia, Sistem Pendidikan Nasional, Bandung: Citra Umbara, 2003.

Piet A. Sahertian, Supervisi Pendidikan Dalam Rangka Program Inservice Eduacation, Surabaya:.Usaha Nasional, 1990.

Amir Daim Indrakusuma, Pengantar Ilmu Pendidikan, Surabaya: Usaha Nasional, 1973.

Ahmad Rohani HM dan Abu Ahmadi, Pengelolaan Pengajaran. Jakarta: Rineka Cipta, 1995.

Abdul Majid, Perencanaan Pembelajaran, Mengembangkan Standar Kompetensi Guru, Jakarta: PT. Rosda Karya, 2008.

Sanjaya, Wina, Strategi Pembelajaran Berorientasi Standar Proses Pendidikan. Jakarta: Prenada Media Group, 2010. 
E. Mulyasa, Uji Kompetensi dan Penilaian Kinerja Guru, Bandung: PT Remaja Rosdakarya, 2013.

Rika Ariyani, Editor Jurnal Literasiologi. Literasi Kita Indonesia. STAI Syekh Maulana Qori. Merangin Bangko. 